\title{
OBITUARY
}

\section{MR. S. A. J. MOORAT}

It is with deep regret that we record the death on Thursday, 31 January 1974, of Mr. S. A. J. Moorat, formerly Librarian, and latterly Keeper of Western Manuscripts, in the Library of the Wellcome Institute for the History of Medicine.

Samuel Arthur Joseph Moorat was born on 14 May 1892, of an English Catholic family, whose remote ancestral home had been Armenia. He was educated at Stonyhurst and Merton College, Oxford, where he took his degree in 1914. In common with most young men of his generation, he suffered the savage interruption of the First World War, serving with distinction in France and Belgium from 1915 to 1921. He was severely wounded during the Battle of the Somme in 1916 and was commissioned after the Armistice to serve as a Staff Captain under the Directorate of Graves' Registration and Enquiries.

His professional career as a librarian was founded at University College, London, in 1923, where he was one of the earliest students in the recently created School of Librarianship.

A long connexion with the library of Sir Henry Wellcome had begun in 1923 in a voluntary capacity. After an interval of work in the library of the Reform Club, he was appointed in 1926 to the staff of the Wellcome Historical Medical Museum as Sub-Librarian. In 1932, Moorat was promoted Librarian, a position he held until his retirement in 1946.

Paradoxically, it was after his retirement that Moorat began the work for which he will be remembered, the series of monumental catalogues of Manuscripts on Medicine and Science in the Wellcome Library. Working with a speed, diligence and accuracy which would have been creditable in a man half his age, Moorat produced volume one, describing the manuscripts written before 1650, in 1962. Volume two, devoted to manuscripts written after 1650, appeared in two further volumes in 1973, only months before his death in his eighty-second year.

It is difficult to estimate the investment of wide-ranging scholarship and hard work which made these catalogues. Moorat's task was to read and describe almost five thousand manuscripts, ranging over eight centuries in date, written in some fifteen ancient and modern languages. His achievement has ensured for himself the gratitude and respect of future generations of scholars.

A modest and retiring man, almost to a fault, Moorat did not find it easy to make acquaintances. His reticence was legendary among his colleagues, but those who made the effort to pierce the barriers of his shyness discovered a warm and delightful human being, possessing a highly developed sense of humour and a sharp wit, which he would direct at himself or others with an impartial but deadly accuracy.

Moorat's reluctance to leave the work he loved postponed his final "retirement" to the autumn of 1973, when circumstances dictated his move from London to Cambridge. It is sad that he had so short a time in which to enjoy the leisure he so richly deserved. 